\title{
BARRIER ACTIVITIES AND THE COURTS: A STUDY IN ANTI-COMPETITIVE LAW
}

\author{
Nathan IsAacs*
}

In $1884 \mathrm{Mr}$. Justice Field paraphrased the Declaration of Independence and proceeded: ${ }^{1}$

Among these inalienable rights, as proclaimed in that great document, is the right of men to pursue their happiness, by which is meant the right to pursue any lawful business or vocation, in any manner not inconsistent with the equal rights of others, which may increase their prosperity or develop their faculties, so as to give them their highest enjoyment.

The common business and callings of life, the ordinary trades and pursuits, which are innocuous in themselves, and have been followed in all communities from time immemorial, must, therefore, be free in this country to all alike upon the same conditions. The right to pursue them, without let or hindrance, except that which is applied to all persons of the same age, sex, and condition, is a distinguishing privilege of citizens of the United States, and an essential element of that freedom which they claim as their birthright.

At that very moment state legislatures were instituting a movement to bar many persons from access to the market unless or until they were licensed by the proper authorities. Lawyers, physicians, plumbers, architects, auctioneers, dealers in secondhand goods, pawnbrokers, barbers, druggists, peddlers, liquor dealers, victuallers, accountants, butchers and bakers-these were only the vanguard of trades and professional men so restricted. Within twenty years after Field spoke, an encyclopedia of law was able to enumerate among the persons whose occupations had been declared to be properly subject to license practically every type of businessman operating at the turn of the century. ${ }^{2}$ Of course not every one of these businesses had been subjected to licenses everywhere. But if we look into the cases cited to support the inclusion of each type of tradesman in the list, we see a series of little court battles in which men who believed as Field did were beaten one by one, until a revolution had been fought and won by new forces.

* A.B., 1907, A.M., rg08, Ph.D., I9ro, LL.B., I9ro, University of Cincinnati; S.J.D., 1920, Harvard University. Professor of Business Law, Graduate School of Business Administration and Graduate School of Public Administration, Harvard University. Editor (with Roscoe Pound), The NAtronar Law Library (1939), and the University Business Book Series. Author, The Law in Business Problems (rev. ed. 1934). Contributor to Encyclopaedia Britannica (1930), Encyclopaedia of the Soctal SCIENCES (I931-35), and various legal and business periodicals.

${ }^{1}$ Butchers' Union Co. v. Crescent City Co., III U. S. 746, 757 (1884). A contemporancous vicw strikingly parallel in its attitude is to be found in Chaddock v. Day, 75 Mich. 527, 42 N. W. 977 (I889).

${ }^{2}$ See (xg07) 25 Crc. 6rr-621. 
The pioneer stage of American civilization had passed. The state and locality could bar any man's access to the market as a seller of goods or services. It is of course true that its officers had no right to act arbitrarily, and the laws had to have some relation to public health, safety and morals, for licensing laws were regarded as emanating from the police power. But it is also true that licensing officers were and had to be endowed with a broad discretion, which in the absence of manifest bad faith they exercised with finality. That this discretion was frequently abused by dishonest authorities is beyond question. That it was also abused by persons who considered themselves honest and actuated by the highest motives is more important for us at the moment. Almost every extension of the licensing power of a state to a new industry is traceable to the wishes of men in that industry. Many of these have readily believed that they were working for higher standards of training, character and responsibility in their trade or profession. Actually they were at the same time succeeding in keeping the "outs" out, and thus limiting their own competition. Quite generally, men already in the trade or profession were automatically licensed or exempted from the requirement, and the commissioners and examiners entrusted with the bestowing or withholding of the licenses were recruited from these ranks. By raising or lowering standards they could control the numbers of persons given access to the market, and sometimes by requiring various kinds of sponsorship they could discriminate against newcomers, or in favor of apprentices previously approved by their own group, or in favor of certain schools, particularly local schools.

After more than a generation of the assumption of such power by license commissioners, the case of New State Ice Company v. Liebmann ${ }^{3}$ came as a jolt in 1932. The statute of Oklahoma separated from the actual granting of a license the task of ascertaining whether existing licensed facilities for the manufacture of ice were "sufficient to meet the public needs." The holding of the Court was that certificates of convenience and necessity had no application outside of the realm of public utilities and allied situations. It was remarked in passing that," "The control here asserted does not protect against monopoly, but tends to foster it. The aim is not to encourage competition but to prevent it; not to regulate the business, but to preclude persons from engaging in it." The suggestion that a state has no power to limit competition by limiting access to the market did not go unchallenged. The dissenting opinion of Mr. Justice Brandeis on the need of economic experimentation by the states is notable not only for its economic and political theory, but for its reflection of existing tendencies in other parts of the current law regulating access to markets.

The indulgent attitude of courts has continued in dealing with licensing regardless of the suspicion, cast on many of the laws and their administration, that they had little to do with public health, safety or morals. It is only in extreme cases that the mask has been torn from municipal trade barriers parading as licensing

${ }_{285}$ U. S. 262 (1932).

4Id. at 279. 
laws. A few recent examples on both sides of the line will illustrate the point. In Real Silk Hosiery Mills, Inc. v. City of Portland, 5 a license tax imposed on solicitors taking orders for hosiery to be shipped to buyers from another state was held to be an intolerable burden on interstate commerce. In Saidel $v$. Village of Tupper Lake, it was said that if the real purpose of an ordinance was to stifle competition and increase the business of dealers operating stores in a village, the ordinance could not be sustained, although it purported merely to require a license for the soliciting of orders in the village for future delivery of goods. Finally, in the case of Best \& Co., Inc. v. Maxwell,? a state "privilege tax law" embodying the provisions usually found in such licensing ordinances was declared invalid by the Supreme Court. In the course of his opinion, Mr. Justice Reed said: ${ }^{8}$

In each case it is our duty to determine whether the statute under attack, whatever its name may be, will in its practical operation work discrimination against interstate commerce. This standard we think condemns the tax at bar. . . . Interstate commerce can hardly survive in so hostile an atmosphere.

The decision is all the more illuminating for our purpose because the "ostensible reach of the language" of the statute included local as well as out-of-state merchants who might choose to display samples in a hotel room or similar quarters for the purpose of securing retail orders. The Court detected the actual discrimination concealed under the non-discriminatory words.

The inspection of goods and wares is closely akin to licensing in principle and in the opportunities afforded for abuse. It is, of course, in the main a legitimate means of barring market access to undesirable goods. Apart from administrative abuses tending to favor certain producers, products or localities, inspection laws are frequently connected with certain fees and other expenses that make them prohibitive for some sources of supply. The outstanding examples here are in the dairy industry. If cities may insist on excluding milk or milk products not inspected at the source, if they may charge the outlying dairy the full cost of the time, the mileage and the use of equipment for inspection, they may intentionally or unintentionally be cutting off that dairy from access to the city's market. So far this particular complaint of dairies has not been passed on in the courts. But in Hale v. Bimco Trading, Inc., ${ }^{9}$ a Florida statute exacting I5 cents a hundred pounds for the required inspection of all imported cement was held invalid, in view of the immunity of domestic cement from the requirements of the statute and the admission that the fee was sixty times the actual cost of inspection.

A variant of inspection laws and ordinances is found in the sticker ordinances tried in Dayton, Ohio, and some other cities. In City of Dayton v. Bohachek $k^{10}$ the following ordinance was challenged:

${ }^{5} 268$ U. S. 325 (1925).

${ }^{\circ} 254$ App. Div. 22, 4 N. Y. S. (2d) $8 \mathrm{I}_{4}$ (1938). ₹3rr U. S. 454 (1940).

${ }^{8}$ Id. at $455-456$.

${ }^{10} 26$ Ohio L. Abs. 417 (Ohio App. 1938), appeal dismissed in the Ohio Supreme Court, May 4, ז938. 
It shall be unlawful for any person to sell, exchange or install . . . any fixture . . . whether new or second hand unless the same has securely attached thereto a label or sticker containing thereon the name "City of Dayton," a serial number and the signature of the plumbing inspector of the City of Dayton or facsimile of such signature engraved thereon.

The court placed some reliance upon the unreported Missouri case of Mound City Plumbing Supply Co. v. Dickman, ${ }^{11}$ which had held an identical St. Louis ordinance unconstitutional. It is not clear on the face of the ordinance nor in the short opinion of the court what was sought to be accomplished or what was feared as a result of this inspection ordinance. Presumably it created the possibility of administrative discrimination against certain products, new or second-hand, or against particular channels of distribution.

The requirement of branding, labeling, or otherwise distinguishing a product has occasionally been resorted to for administrative purposes. But when the requirement goes so far as coloring oleomargine pink or out-of-state milk red, it gives up all pretense of reasonableness. ${ }^{12}$

Several of the cases already cited under licensing and inspection involve also taxation as a method of barring persons or goods from access to the market. Taxation as a means of encouraging or discouraging particular activities is of course nothing new. Nor are the courts so naive as to insist that taxation must be only for revenue. They have tolerated luxury taxes, compensatory taxes, prohibitive or destructive taxes of various kinds. Why not, therefore, taxes calculated to make the market more or less accessible for chosen persons, commodities, localities? The answer is roughly that while taxing is a permissible alternative means of accomplishing lawful ends, it does not open the door for unlawful objectives. If a particular discrimination is prohibited to the state legislature, the fact that it is to be accomplished solely by taxation is of no avail. The difficulty arises in applying this general principle.

Taxation has been resorted to as a means of barring access to the market (I) in the fight among states and localities for business advantages, (2) in the history of chain-store legislation, and (3) in government favoritism in product competition. In the use of taxation in the setting up of interstate barriers, the obvious difficulty encountered has been the interstate commerce clause. The attitude of the Supreme Court on the applicability of this clause has undergone an interesting development. Whether we begin with Marshall's idea that the clause automatically deprives states of all powers to legislate on subjects within the meaning of the term, or with Taney's, that it merely makes congressional action override state action or the possibility of

\footnotetext{
${ }^{11}$ Decision by Kirkwood, J., Div. No. 3, St. Louis, Mo., cited id. at 418.

${ }^{13}$ In the case of Collins v. State of New Hampshire, I7I U. S. 30 (1898), a statutory requirement that oleomargarine sold within the state be so colored was held void as to interstate commercial transactions. Rhode Island's "red milk" is cited in Taylor, Burtis and Waugh, Barriers to Internal Trade in Farm Products (U. S. Dep't Agric., 1939) II; Hearings Before the Temporary National Economic Committee, 76th Cong., 2d Sess. (1940) Pt. 29, at 16124, Exhibit 2354.
} 
state action, ${ }^{13}$ we reach a point where it becomes necessary to determine what are the subjects of interstate commerce, how long they remain such, and what types of interference by states will not be tolerated.

The judges of the nineteenth century were fond of categorical answers to these questions. They listed the subjects of interstate commerce, they laid down such tests as the original package doctrine, and they made such dogmatic announcements as that of the Robbins case, ${ }^{14}$ that "Interstate commerce cannot be taxed at all, even though the same amount of the tax is laid on domestic commerce...." From such positions they have now receded. We no longer have a list of subjects of interstate commerce; on the contrary, one and the same activity may be interstate for some legal purposes and intrastate for others..$^{15}$ The original package doctrine, applied originally to the local taxation of imports, ${ }^{16}$ was shied away from when interstate shipments were held to be neither imports nor exports in the constitutional sense, ${ }^{17}$ and today it presents a mere circumstance to be taken together with many other considerations in deciding a question of fact. Finally, the doctrine that interstate commerce cannot be taxed by a state has been abandoned. In I929, Mr. Justice Stone declared in a concurring opinion that interstate commerce must pay its own way. ${ }^{18}$ In 1932, Mr. Justice Holmes repeated the statement in delivering an opinion of the Court. ${ }^{19}$ This declaration rendered obsolete a whole beadline of cases in which the nontaxability of interstate commerce was the major premise. ${ }^{20}$ It paved the way for property taxes on articles used or moved in interstate commerce, ${ }^{21}$ for gasoline taxes, ${ }^{22}$ for use taxes, ${ }^{23}$ and eventually for sales taxes levied by the state of the buyer. ${ }^{24}$ The precise tacking by which the Supreme Court accomplished its change of direction does not concern us here so much as does the fact that there has been a change of direction. ${ }^{25}$

To resist a tax today requires proof of discrimination against interstate commerce, "hostility" to interstate commerce as members of the Court have several times expressed it. ${ }^{26}$ There is, however, no assurance that a type of tax considered

${ }^{23}$ See Jackson, The Supreme Court and-Interstate Barriers (1940) 207 AnNals 70-72.

14 Robbins v. Shelby County Taxing District, r20 U. S. 489, 497 (1887).

${ }^{20}$ Virginia Ry. Co. v. System Federation No. 40, 300 U. S. 515 (1937).

${ }^{28}$ Brown v. Maryland, 12 Wheat. 4 I9 (U. S. 1827 ).

${ }^{17}$ Woodruff v. Parham, 8 Wall. 123 (U. S. 1869). ' Cf. Powell, New Light on Gross Receipts Taxes (1940) 53 HARv. L. Rev. 909, 935. ${ }^{18}$ Helson et al. v. Kentucky, 279 U. S. 245,253 (I929).

${ }_{10}$ New Jersey Bell Telephone Co. v. Tax Board, 280 U. S. 338, 35 I (1930).

${ }^{20}$ Not quite obsolete for, oddly enough, these cases are cited when abuse of the power to tax interstate commerce is in question, as in the case of Best \& Co., Inc. v. Maxwell, stupra note 7. For a collection of the cases, see Lockhart, The Sales Tax in Interstate Commerce (r939) 52 Hanv. L. Rev. $6 \mathrm{r} 7,6 \mathrm{r} 8$, n. $x$.

21 Wiloil Corp. v. Pennsylvania, 294 U. S. I69 (I935).

${ }^{22}$ Gregg Dyeing Co. v. Query, 286 U. S. 472 (x932).

${ }^{23}$ Henneford v. Silas Mason Co., 300 U. S. 577 (1937).

${ }^{28}$ Sears, Roebuck v. McGoldrick, 279 N. Y. 184, 18 N. E. (2d) 25 (r938); McGoldrick v. BerwindWhite Coal Mining Co., 309 U. S. 33 (r940); Nelson v. Sears, Roebuck \& Co., 6r Sup. Ct. 586 (1941).

${ }^{25}$ See William B. Lockhart's comprehensive studies on The Sales Tax in Interstate Commerce, stipra note 20; and State Tax Barriers to Interstate Trade (1940) 53 id. 1253.

${ }^{28}$ E.g., in Best \& Co., Inc. v. Maxwell, supra note 7, and in the opinion of Justices Black, Frankfurter and Douglas in McCarroll v. Dixie Greyhound Lines, 309 U. S. 176, 183 (1940). 
"hostile" in one case will always be so treated. Among the taxes recently condemned are the following: a gasoline tax said by the Court to fall directly on the use of a ferry in interstate commerce; ${ }^{27}$ a statute taxing all gasoline in excess of twenty gallons carried by a car entering a state, regardless of the actual road use contemplated within the state; ${ }^{28}$ and the North Carolina tax on the user of a hotel showroom. ${ }^{29}$ And among the taxes found innocent are these: a use tax on goods brought into the state and stored there; ${ }^{30}$ the mail-order tax on goods brought into the buyer's state; ${ }^{31}$ the sales tax on coal shipped into New York City $;^{32}$ the sales tax on goods ordered in New York City and sent in from out-of-state warehouses where they had been stored for the convenience of the dealer; ${ }^{33}$ the tax on goods bought and delivered within a state where it was a matter of indifference so far as the contract of sale was concerned whether they came in from out of the state or not; ${ }^{34}$ a tax on storage and withdrawal of oil that had been brought in from outside of the state; ${ }^{35}$ and a tax on gasoline sold to an interstate air liner. ${ }^{36}$

Sales taxes and use taxes have so far been carefully drawn in order to subject goods brought into the state to the same tax paid by domestic goods sold within the state. Of course if we look at the specific facts in any case we may find double taxation. Double taxation, however, is not in itself unconstitutional. It is desirable, of course, to avoid it-and legislatures as well as courts have tried to do so. But so long as imported goods are not subjected to a heavier tax in the buyer's state than that on domestic goods, there seems to be no constitutional ground of complaint. The same logic might be applied to sales taxes in the seller's state levied on goods shipped out of it in interstate commerce. It is not likely to be, because a tradition has already been established of regarding these taxes as taxes on the buyer. Viewed as such, they are beyond the reach of the seller's state. ${ }^{37}$

The study of a trend of legal decisions is never free from a consideration of the personal attitude of judges, particularly, in constitutional questions, of the justices of the Supreme Court of the United States. A school of law has grown up that seeks an underlying unity in the judicial pronouncements and writings of each judge. There is, of course, a good deal of danger in basing one's conduct on provisos drawn up on such a basis. By no means all arguments of counsel are predestined to fall on deaf ears. Judges themselves sometimes change their approach and at other times, without attempting any change of approach, draw remarkable distinctions. They are no more bound than any other human being to pursue to

${ }^{2 T}$ Helson et al. v. Kentucky, supra note 18 .

${ }^{28}$ McCarroll v. Dixie Greyhound Lines, supra note 26.

29 Best \& Co., Inc. v. Maxwell, supra note 7.

${ }^{30}$ Southern Pacific Co. v. Gallagher, 306 U. S. I67 (1939).

${ }^{81}$ Nelson v. Sears, Roebuck \& Co., supra note 24 .

${ }^{22}$ McGoldrick v. Berwind-White Coal Mining Co., supra note 24 .

${ }^{33}$ Sears, Roebuck v. McGoldrick, supra note 24. 34 Wiloil Corp. v. Pennsylvania, supra note 21.

${ }^{85}$ Nashville, Chattanooga \& St. Louis Ry. v. Wallace, 288 U. S. 249 (1933).

${ }^{30}$ Edelman v. Boeing Air Transport, Inc., 289 U. S. 249 (1933).

${ }^{87}$ O'Kane v. New York, 283 N. Y. 439,28 N. E. (2d) 905 (1940). See Note, Validity of Sales Tax by Seller State on Interstate Transactions (1940) 26 CoRn. L. Q. 158; (1941) 9 Duke BAr Ass's J. 54 . 
logical conclusions all the theories they profess. There is no clear majority in the present Supreme Court on any major issue with the possible exception of the controlling one: that it is a question of common sense in each case whether a particular burden imposed on interstate commerce is primarily and essentially a barrier or only incidentally and accidentally such. In other words, there is no majority on the question whether it makes a difference that the goods are at the time of the imposing of the burden outside of the state. There is no clear majority on whether it makes a difference that there is a necessary contemplation that goods will be brought across state borders in the fulfillment of the contract. There is no majority on the question whether the buyer's state need pay any attention to what happens in the seller's state or whether they are to be dealt with on the same principles or on different principles. The grouping of the justices, particularly on the basis of McCarroll v. Dixie Greyhound Lines, ${ }^{38}$ while interesting, therefore seems to have been somewhat overemphasized as an indication of the trend. What is more important at the moment is the obvious necessity for courts, legislatures, and administrators alike to recognize the increasing need for taxation and regulation and the necessity of making some reasonable compromise between the interests of the people as citizens of the states and of those same people as citizens of the United States in keeping the channels of interstate commerce open without draining those of intrastate commerce.

Taxation, we have said, has been used in the fight against chain stores. The story has been told in detail elsewhere. ${ }^{39}$ We are concerned here merely with one aspect of the judicial reaction to such efforts. If certain crudities and technical collisions with state constitutions are avoided, taxation can be used as a heavy weapon against chain stores, or any other singled-out variety of store, such as the supermarket or the department store. ${ }^{40}$ It is curious to contrast the boldness of taxation experiments in this connection, with the conservatism of use tax legislation. The Camden basket law ${ }^{41}$ which penalized self-service stores in which baskets were supplied for the convenience of shoppers may be an extreme instance. Courts still have much of the task before them of drawing the line between allowable and purely arbitrary taxes that discriminate against the too-powerful competitor.

Taxes have been used to favor particular products and to keep others from the market. The outstanding cases come under the oleomargarine laws of dairy states and the retaliatory legislation of states producing particular vegetable oils. The Magnano case ${ }^{42}$ seemed to put the stamp of approval on this type of legislation. What it really decides in law may be more fairly stated as the propriety of such

${ }^{38}$ Stcpra note 26 .

${ }^{39}$ Feldman, Legislative Opposition to Chain Stores and lts Mininization, supra this issuc.

${ }^{40}$ The series of cases establishing the general principle include: State Tax Comrs. v. Jackson, 283 U. S. 527 (1931); Fox v. Standard Oil Co., 294 U. S. 87 (1935); Great A. \& P. Tea Co. v. Grosjean, 301 U. S. 412 (r937). Liggett Co. v. Lee, 288 U. S. 517 (1933), is an illustration of an arbitrary and hence unconstitutional mode of calculation of the tax.

${ }^{11}$ Great A. \& P. Tea Co. v. Com'rs, 122 N. J. L. 47, 4 A. (2d) x6 (1939).

${ }^{2}$ A. Magnano Co. v. Hamilton, 292 U. S. 40 (1934). 
legislation in the absence of an illegal motive and the presumption of the absence of illegal motives in a legislative body. These propositions of law are unimpeachable, but there is still a valid question as to how blind a court should be to what everyone else can see. It seems probable that a court is more likely to indulge in the presumption of regularity and legality of object when a commodity discrimination is involved than when a purely personal discrimination is presented.

Particularly difficult will be the lot of the manufacturers and sellers of intoxicating liquors who object to discriminatory taxes. In attempting to protect dry states against the inflow of liquor from wet states, the Repeal Amendment used broad language: ${ }^{43}$

The transportation or importation into any State, Territory or Possession of the United States for delivery or use therein of intoxicating liquors in violation of the laws thereof, is hereby prohibited.

This language permits wet states as well as dry to set up their own laws as to the importation of liquor. Hence even outspoken plans for trade barriers are upheld. These are generally prohibitions presented in the form of tax discriminations.

Recently a miscellaneous group of legislative enactments has come into existence that presents if not a new at least a novel approach to the problem of controlling access to the market. The common fault that runs through most of these is the prohibition of new, unorthodox methods of reaching the public. From the lawyer's point of view these cases go back to Rast $v$. Van Deman and Lewis ${ }^{44}$ and related cases, where it will be remembered the use of trading coupons, prize packages and that sort of thing came into collision with the legislative conception of public welfare, or possibly to the Liggett case, ${ }^{45}$ in which the statute sought to oust chain drug stores. The modern cases differ from the older ones, however, in that the public aspect of the controversy is wholly lacking, or at least very thin. An excellent example is found in Kress $\&$ Co. v. Johnson. ${ }^{46}$ The act in question forbade the conducting of a restaurant in any room where merchandising was carried on. The act was held constitutional. Rarely has judicial tolerance and indulgence in favorable presumptions of legislative reasoning gone further. In the same spirit an ordinance prohibiting the installation and operation of "automatic coin-in-the-slot" gasoline pumps has been upheld as a proper exercise of police power. ${ }^{47}$

Under the guise of police power there are each year proposed-and often enacted-bills to discourage new devices for all kinds of business. Paper containers are not to be used for milk; ${ }^{48}$ grocery stores are not to sell camphorated oil; ${ }^{49}$ door-to-

${ }^{4}$ U. S. Const., Amend. XXI, \$2. See State Board of Equalization v. Young's Market Co., 299 U. S. 59 (1936), and cases following it; Carr, Liquor and the Constitution (1940) 7 LAw \& ConteMP. Pros. 709; Note (1938) 38 Col. L. Rev. 644.

“ 240 U. S. 342 (1916).

${ }^{45} 278$ U. S. 105 (1928).

${ }^{10}$ I6 F. Supp. 5 (D. Colo. I936), aff'd, 299 U. S. 5 II (I936).

"Hawkins v. City of Red Cloud, 123 Neb. 487, 243 N. W. 43I (1932).

${ }^{48}$ Ex-Cell-O Corp. v. City of Chicago, II5 F. (2d) 627 (C. C. A. 7th, 1940).

${ }^{10}$ Board of Pharmacy v. Abramoff, 6 N. J. Misc. Iro9, r43 Atl. 764 (r928). 
door selling is declared a nuisance; ${ }^{50}$ markets must not supply baskets as a convenience to shoppers; ${ }^{51}$ ice cream vendors must not offer their wares except in the hours when they are least likely to sell them; ${ }^{52}$ a retailer may not manufacture; ${ }^{53}$ a department store must have as many doors to the street as it has departments; ${ }^{54}$ local agents must participate in the writing up of insurance risks; ${ }^{55}$ prefabricated houses run into building code difficulties. ${ }^{56}$ It is idle to forecast in which of the cases that have not yet been adjudicated the courts will choose to see the private economic motives to the exclusion of the constitutional pretense of public interests.

We have been discussing selected instances of publicly created market barriers. At some points they come perilously near to the private efforts in the same direction that have been condemned under the anti-trust acts. To what extent is a state law or a municipal ordinance to be regarded as a shield against prosecutions? Thus, if the grocers of a town were to conspire among themselves to keep a newcomer out, they might readily find themselves in the toils of the law. If instead, they conspire with a friendly city council to interpose tax, license, inspection and other hurdles-are they any the less guilty of a violation of the spirit or even the very letter of the anti-trust laws?

Anti-competitive state laws and ordinances, if they work at all, tend to destroy competition or eliminate competitors. In fact, the key to the whole trend that we have been examining is found in the new tolerance of courts as well as legislatures toward anti-competitive laws. The tendency has been obscured, of course, by a persistent refusal to call these laws by their proper names. The Federal Trade Commission unfortunately has no power to prevent legislatures from misbranding their laws. Congress itself set the example when it passed an act stopping competition at the vital point where the retailer stocks his shelves and called it an antitrust law. The fair-trade acts have no more to do with fairness than did the codes of fair competition under the National Recovery Act. They attempt to cut off competition at the other vital point where the retailer passes on his goods to the consumer. The anti-loss-leader acts, by whatever name they are called, are likewise limitations on the freedom of competition. Now comes an avalanche of little laws calculated to keep from the market, under one pretense or another, the competition of certain persons, certain commodities, certain localities. The demand for these laws, the legislative response and the tolerance of the courts all reflect the same departure from the philosophy of the nineteenth century. We no longer believe in self-starting, automatically-controlled competition as nature's sacred device for regulating markets. We are quite willing to admit that some competition may be disagreeable and we venture at times to put forth a hand to steady it.

${ }^{60}$ Town of Green River v. Fuller Brushi Co., 65 F. (2d) 112 (C. C. A. Ioth, 1933).

"1 Great A. \& P. Tea Co. v. Com'rs, supra note 41 .

${ }^{52}$ Good Humor Corp. v. Long Beach, 22 N. Y. S. (2d) 382 (1940).

${ }^{28}$ Robertson v. Commonwealth, 168 Va. 752, r9x S. E. 773 (1937); the Patman anti-chain bill, discussed in Cook, Legislative Restrictions on Marketing Integration, sttpra this issue.

EI Isarcs, Business Law (Nat. Law Lib., r939) 203. ${ }_{55}$ Osborn v. Ozlin, 310 U. S. 53 (1940).

${ }^{58}$ State ex rel. v. Yoter, 65 Ohio App. 492, 30 N. E. (2d) 558 (1939). 